\title{
Empirical Assessment and Application of SERVQUAL Evidence from UAE Banks
}

\author{
Mansour S. M. Lotayif ${ }^{1}$ \\ ${ }^{1}$ Business Department, Faculty of Commerce, Beni-Suif University, Egypt \\ Correspondence: Mansour S. M. Lotayif, Business Department, Faculty of Commerce, Beni-Suif University, \\ Egypt. Mansourlotayif@hotmail.com
}

Received: January 13, 2017

Accepted: March 20, 2017

Online Published: March 26, 2017

doi:10.5539/ijbm.v12n4p197

URL: https://doi.org/10.5539/ijbm.v12n4p197

\begin{abstract}
The current research aims at identifying the causality relationships between SERVQUAL dimensions i.e. tangibility, reliability, responsiveness, assurance, and empathy and demographics i.e. gender, age, income, education, and occupation. The reliability and validity of Parasuraman's instrument were tested in a developing nation i.e. UAE. Moreover, quality of banking services will be assessed in UAE. The experiences of 537 customers were utilized to achieve these objectives. Throughout Multiple Regression in SPSS package, significant relationships between each SERVQUAL dimension and demographics were supported. However, the explanation powers of these models are still weak. Throughout WSRT, baking services' quality still lags behind the expectations of UAE inhabitants.
\end{abstract}

Keywords: Research paper, SERVQUAL, service quality, expectations, perceptions, and UAE

\section{Introduction}

Literally, every service provider is keen in offering excellent services to stay in business; however the meaning of excellence remained a debated issue in the literature till recently. Bearing in mind that service quality (SQ) is viewed as the major strategic variable (i.e. a key strategic competitive weapon as perceived by Berry, (1994); Kelley, (1993, and 1992) for instance) in the battle for a decent market share and excellent service is the critical corporate priority (Ghobadian et al., 1994). Moreover, quality jargon is considered a slippery concept that is easy to be visualized and difficult to be defined (Garvin, 1988). In fact, quality could be viewed from different angles and approaches; it is the conformance to specifications as seen by production-oriented scholars (Kasper et al.,1999; Oliver, 1997), and it is the subjective customer perception as seen by customer-oriented scholars (e. g. Rust and Oliver, 1994). All in all, customer's eye is the main determinant of quality (Gummesson, 1991). Here is the focal point which loaded quality upon customer perception. In contrary, poor service has been identified as the primary reason why customers switch to competitors (Philip \& Hazlett, 1997). The emergence of SERVQUAL scale determines, in a practical way, the meaning of quality in the eyes of customers. The fact of the matter, SERVQUAL is a useful starting point, not the final answer, for assessing and improving service quality (Parasuraman et al., 1991, p. 445).

\section{Previous Work}

Parasuraman et al. $(1991 ; 1988 ; 1985)$ introduced the first iteration of SERVQUAL scale for measuring service quality. As originally proposed, SERVQUAL consists of two sections: a 22-item section to measure customers' service expectations of companies within a specific sector and a corresponding 22-item section to measure customers' perceptions of a particular company in that sector (Parasuraman et al., 1991, p. 421). This 22-item scale measures five constructs: tangibles (4 items), reliability ( 5 items), responsiveness (4 items), assurance (4 items), and empathy (5 items). However, they were 10 constructs on the first iteration suggested at 1985 . The essence of this scale is based on measuring the quality of offered services by determining the gap between customer expectations and perceptions (P-E). This gap approach will determine the level of satisfaction and loyalty afterward (Davidow \& Uttal, 1989), as good service quality means that the customers' perceptions of service performance meet or exceed their expectations (Zhao et al., 2002). More specifically, the higher the perception-minus-expectation (P-E) score is, the higher the level of perceived service quality will be (Lam \& Woo, 1997, p. 382). 
Once suggested, the literatures of SERVQUAL scale have been centered in two streams. Firstly, using SERVQUAL, in its original iteration, as a tool to measure service quality and testing its validity and reliability e.g. Stodnick and Pamela (2008); Klaus and Stan, (2007); Ugboma et al. (2007); Yavas (2006); Fatma and Harwood (2005); Wisniewski (2001); Mcatarsney (1999); Pariseau and McDaniel (1997); and Reeves and Bednar (1994). Secondly, suggesting minor and major amendments on the original iteration of SERVQUAL e.g. Aga and Okan (2007); Hughey et al., (2003); Zhao et al., (2002); Oldfield and Baron (2000); Donnelly and Shiu (1999); Philip and Hazlett (1997); Cuthbert (1996); and Mittal and Lassar (1996).

Firstly, in education context, Stodnick et al. (2008) deployed SERVQUAL scale (five dimensions with 22 items) to measure student perceptions of service quality and their findings supported SERVQUAL reliably and validity, especially convergent and divergent validity. In shipping context, Ugboma et al. (2007) used the SERVQUAL scale to assess the offered services in two Nigerian ports. Yavas (2006) used the 22-item SERVQUAL scale to measure the customer perception of banking services in Turkey. However, Yavas's study did not approve the same five constructs as the factor analysis revealed. In their study in healthcare context, Fatma and Harwood (2005) found that SERVQUAL model is useful in figuring out the differences between patients' expectations and actual performance. In computer labs context, Hughey et al. (2003) found SERVQUAL scale (22 items) have been loaded onto three factors: staff, services, and professionalism. Also, Oldfield and Baron (2000) found SERVQUAL items centered around three dimensions: requisite, (essential items enables students fulfill their study obligations); acceptable, (items that are preferable rather than essential to student development), and functional (items outside the control of the instructor but are driven from university rules). Wisniewski (2001) used the gap approach (P-E) to evaluate the performance of seven Scottish councils: catering service, building control, development control, grounds maintenance, housing repairs, leisure services, and library services. With regards to library services for instance, the gap was positive with three SERVQUAL dimensions (i.e. responsiveness, assurance, and empathy), as the perception exceeded the expectation with these service dimensions. And negative gap were found with tangibles and reliability dimensions. However, all service managers in Wisniewski's study found the service quality gap and SERVQUAL dimensions were conceptually attractive and operationally useful.

Moreover, Mcatarsney (1999) used, also, the gap approach to assess the quality levels in hospitality, leisure, and entertainment industry in a UK-based small and medium enterprise (case study). Unlike the previous studies, Lam and Woo (1997) have used test-retest reliability to evaluate the long and short-term stability of SERVQUAL scale. The results indicated that the SERVQUAL scale was not stable over time as revealed by the insignificant correlation between the test scores and retest scores. On the same line of literature, Pariseau and McDaniel (1997) found that SERVQUAL scale was useful as an instrument for benchmarking performance to improve service quality in schools of business. Finally, Reeves and Bednar (1994) considered the strengths and weaknesses of the original iteration of SERVQUAL. Having said that, culture environment affect on customer perception of quality, which might be an obstacle on generalizability of SERVQUAL scale (Zhao et al., 2002; Mattila, 1999; Donthu \& Yoo, 1998; Babakus \& Boller, 1992).

Secondly, in professional accounting context, Aga and Okan (2007) found SERVQUAL scale with its 19 items, and five dimensions, provides good measurement of service quality. Zhao et al., (2002) did not approve the same five constructs as the findings from the Chinese market (i.e. Mainland Chinese Department Store) indicated and suggested further research in this area. Donnelly and Shiu (1999) added three more items, as suggested by a focus group, to the original 22-item SERVQUAL scale suggested by Parasuraman et al. (1990). In that study and after conducting the factor analysis (FA), the data collected did not support the five constructs previously suggested by Parasuraman et al. (1990). However, the presentation of FA was misleading, as factors with eigenvalues less than unity should not be considered in determining the number of factors as suggested by statisticians e. g. Bryman and Cramer (2001); and Hair et al. (1998). Philip and Hazlett (1997) shifted the direction of SQ studies to another direction by suggesting what so-called P-C-P model that has three hierarchical levels: pivotal (outputs), core and peripheral that jointly representing inputs (i.e. personnel and processes which means the organizational structure). Consequently, it is believed that P-C-P model differ from SERVQUAL in the following aspects: the deliverables, the measurement scale, and the importance each dimension has. More specifically, SERVQUAL makes no distinction between the "deliverables" and "personnel and organizational hierarchies" involved in the provision of that service. The P-C-P attribute model does not rely on the separate measurement of customer expectations and perceptions, as does the SERVQUAL scale. Finally, the P-C-P model proposes to assign different weights to each of its three levels of attribute groupings, but the original SERVQUAL scale makes no distinction in the level of importance it attaches to each of its five dimensions. In the P-C-P model, more weight is given to the achievement of the pivotal attributes, followed in turn by the core 
and peripheral attributes respectively.

Annex, Mittal and Lassar (1996) focused on the personalization process (i.e. the nature of interpersonal interaction) in service delivery. They differentiated amongst personalization, customization and responsiveness, as the latter two jargons might be offered with complete personalization. They added personalization as the fourth SERVQUAL diminution (i.e. tangibles, reliability, responsiveness, and personalization). The modified 16-item termed "SERVQUAL-P". In their study, personalization as a significant predictor in service quality is proved. However, the subjective way used in determining the components of personalization dimension (i.e. three colleagues in the discipline have been used as judges and were asked to sort out those mostreflective of personalization according to the definition provided) could be one of their study's minuses that need further corroboration of its findings. Cuthbert (1996) after conducting a factor analysis test, reached to a SERVQUAL scale with seven dimensions. In that study and due to low magnitude of Cronbach alpha that ranged between 0.01 and 0.52 , the author concluded that using the SERVQUAL scale to measure university service quality seems inappropriate.

Consequently, the current study adopted the first stream of literature that uses SERVQUAL scale in its original iteration to refine and assess the banking services in UAE. Therefore, assessing reliability and validity, using SERVQUAL to assess banking services, and modeling the variables that affect both service perception and expectation represent the current study's aims.

\section{Study Objectives}

The current study is oriented to achieve the followings:

1. Modeling the variables that affect the expectations and perceptions of banking services through segment customers into perceived and expected quality categories on the basis of their individual SERVQUAL scores and these segments can then be analyzed in conjunction with demographics as suggested by Lewis (1996) and Lewis and Mitchell (1990) and conducted by Mittal and Lassar (1996);

2. Using SERVQUAL scale to evaluate the offered services' quality by UAE banks; and

3. To empirically assess the reliability and validity of SERVQUAL scale in a developing country i.e. UAE.

\section{Research Hypotheses}

The above objectives will be achieved throughout the underneath hypotheses. Hypotheses $(\boldsymbol{H} 1 \boldsymbol{E}),(\boldsymbol{H} 2 \boldsymbol{E}),(\boldsymbol{H} 3 \boldsymbol{E})$, (H4E), (H5E), (H1P), (H2P), (H3P), (H4P), and (H5P) help serve the first objective. And for the second objective, hypothesis (H6) is designed. Scale reliability and validity will be tested throughout Cronbach alpha coefficient and factor analysis respectively.

H1E: "There is a significant relationship between the expected service tangibility and UAE customer's gender, age, income, occupation, and education".

H1Ea: "There is a significant relationship between the expected service tangibility and customer's gender";

$\boldsymbol{H 1 E \boldsymbol { E }}$ : "There is a significant relationship between the expected service tangibility and customer's, age";

H1Ec: "There is a significant relationship between the expected service tangibility and customer's income";

H1Ed: "There is a significant relationship between the expected service tangibility and customer's occupation"; and

H1Ee: "There is a significant relationship between the expected service tangibility and customer's education".

H2E: "There is a significant relationship between the expected service reliability and UAE customer's gender, age, income, occupation, and education".

H2Ea: "There is a significant relationship between the expected service reliability and customer's gender";

$\boldsymbol{H} \mathbf{E} \boldsymbol{E} \boldsymbol{b}:$ "There is a significant relationship between the expected service reliability and customer's age",

H2Ec: "There is a significant relationship between the expected service reliability and customer's income";

H2Ed: "There is a significant relationship between the expected service reliability and customer's occupation"; and

H2Ee: "There is a significant relationship between the expected service reliability and customer's education".

H3E: "There is a significant relationship between the expected service responsiveness and UAE customer's gender, age, income, occupation, and education".

H3Ea: "There is a significant relationship between the expected service responsiveness and customer's gender"; 
$\boldsymbol{H} \mathbf{B E} \boldsymbol{b}:$ "There is a significant relationship between the expected service responsiveness and customer's age";

H3Ec: "There is a significant relationship between the expected service responsiveness and customer's income";

H3Ed: "There is a significant relationship between the expected service responsiveness and customer's occupation"; and

H3Ee: "There is a significant relationship between the expected service responsiveness and customer's education".

H4E: "There is a significant relationship between the expected service assurance and UAE customer's gender, age, income, occupation, and education".

H4Ea: "There is a significant relationship between the expected service assurance and customer's gender";

$\boldsymbol{H} \mathbf{H E}$ : "There is a significant relationship between the expected service assurance and customer's age";

H4Ec: "There is a significant relationship between the expected service assurance and customer's income";

H4Ed: "There is a significant relationship between the expected service assurance and customer's occupation"; and

H4Ee: "There is a significant relationship between the expected service assurance and customer's education".

H5E: "There is a significant relationship between the expected service empathy and UAE customer's gender, age, income, occupation, and education".

H5Ea: "There is a significant relationship between the expected service empathy and customer's gender";

H5Eb: "There is a significant relationship between the expected service empathy and customer's age";

H5Ec: "There is a significant relationship between the expected service empathy and customer's income";

H5Ed: "There is a significant relationship between the expected service empathy and customer's occupation"; and

H5Ee: "There is a significant relationship between the expected service empathy and customer's education".

H1P: "There is a significant relationship between the perception of service tangibility and UAE customer's gender, age, income, occupation, and education".

H1Pa: "There is a significant relationship between the perception of service tangibility and customer's gender";

H1Pb: "There is a significant relationship between the perception of service tangibility and customer's age";

H1Pc: "There is a significant relationship between the perception of service tangibility and customer's income";

H1Pd: "There is a significant relationship between the perception of service tangibility and customer's occupation"; and

H1Pe: "There is a significant relationship between the perception of service tangibility and customer's education".

H2P: "There is a significant relationship between the perception of service reliability and UAE customer's gender, age, income, occupation, and education".

H2Pa: "There is a significant relationship between the perception of service reliability and customer's gender";

$\boldsymbol{H} \mathbf{2 P \boldsymbol { P }}$ : "There is a significant relationship between the perception of service reliability and customer's age";

H2Pc: "There is a significant relationship between the perception of service reliability and customer's income",

H2Pd: "There is a significant relationship between the perception of service reliability and customer's occupation"; and

H2e: "There is a significant relationship between the perception of service reliability and customer's education".

H3P: "There is a significant relationship between the perception of service responsiveness and UAE customer's gender, age, income, occupation, and education".

H3Pa: "There is a significant relationship between the perception of service responsiveness and customer's gender";

H3Pb: "There is a significant relationship between the perception of service responsiveness and customer's age"; 
H3Pc: "There is a significant relationship between the perception of service responsiveness and customer's income";

H3Pd: "There is a significant relationship between the perception of service responsiveness and customer's occupation"; and

H3Pe: "There is a significant relationship between the perception of service responsiveness and customer's education”.

H4P: "There is a significant relationship between the perception of service assurance and UAE customer's gender, age, income, occupation, and education”.

H4Pa: "There is a significant relationship between the perception of service assurance and customer's gender”;

$\boldsymbol{H 4 P b}$ : "There is a significant relationship between the perception of service assurance and customer's age”;

H4Pc: "There is a significant relationship between the perception of service assurance and customer's income;

H4Pd: "There is a significant relationship between the perception of service assurance and customer's occupation"; and

H4Pe: "There is a significant relationship between the perception of service assurance and customer's education”.

H5P: "There is a significant relationship between the perception of service empathy and UAE customer's gender, age, income, occupation, and education".

H5Pa: "There is a significant relationship between the perception of service empathy and customer's gender";

H5Pb: "There is a significant relationship between the perception of service empathy and customer's age";

H5Pc: "There is a significant relationship between the perception of service empathy and customer's income";

H5Pd: "There is a significant relationship between the perception of service empathy and customer's occupation”; and

H5Pe: "There is a significant relationship between the perception of service empathy and customer's education".

H6: "The expected banking services (i.e. tangibility, reliability, responsiveness, assurance, and empathy) exceed the perceived level of services i.e. tangibility, reliability, responsiveness, assurance, and empathy in UAE”.

H6$_{1}$ : "The expected tangibility dimension in banking services exceed the perceived level of tangibility in UAE";

H6$_{2}$ : "The expected reliability dimension in banking services exceed the perceived level of reliability in UAE";

H6 $_{3:}$ "The expected responsiveness dimension in banking services exceed the perceived level of responsiveness in $U A E$ ";

H6 $_{4}$ "The expected assurance dimension in banking services exceed the perceived level of assurance in UAE"; and

H6 $_{5:}$ "The expected empathy dimension in banking services exceed the perceived level of empathy in UAE".

\section{Study methodology}

This part includes the followings: (1) determining the deployed research paradigm (2) the population from which a representative sample was selected; (3) data collection method; (4) statistical packages and statistical techniques deployed in the current study. Firstly; for research paradigm, positivistic approach throughout using a structured questionnaire was adopted. In the same time, a phenomenological approach through using "discussion groups" of bank executives and colleagues were used to find out explanations and clarifications of both study results and questionnaire's validity. Both paradigms were deployed in a cross sectional study of the UAE banking sector. Interestingly, Zhao et al., (2002) adopted the same approach in investigating the quality performance of a Chinese department store. Secondly, a convenience sample of 600 banks' customers in UAEhas been utilized in the current study. Thirdly, the 22-item SERVQUAL scale suggested by Parasuraman et al. (1985) and modified in (1991) was used. On which a seven-point Likert scale was deployed. Response bases were asked to indicate their expectations and perceptions for each of the 22 items in the questionnaire with ' 1 ' 
indicating 'strongly disagree' and ' 7 ' indicating 'strongly agree' for each one of the 22 statements. The questionnaire is divided into three main parts: (1) demographics; (2) expectation; and (3) perception. Demographic variables are gender, age, income, occupation, and education. The 22-item SERVQUAL scale is divided into five concepts i.e. tangibility (from X1 to X4 in expectation side and from Y1 to Y4 in perception side), reliability (from X6 to X10 in expectation side and from $\mathrm{Y} 6$ to $\mathrm{Y} 10$ in perception side), responsiveness (from X12 to X15 in expectation side and from Y12 to Y15 in perception side), assurance (from X17 to X20 in expectation side and from Y17 to Y20 in perception side), and empathy (from X22 to X26 in expectation side and from Y22 to Y26 in perception side). For the sake of accurate and meaningful analysis, artificial variables have been created. Theses created variables are X5 $\left(\frac{\mathrm{x} 1+\mathrm{x} 2+\mathrm{x} 3+\mathrm{x} 4}{4}\right)$ for expected tangibility and Y5 $\left(\frac{\mathrm{y} 1+\mathrm{y} 2+\mathrm{y} 3+\mathrm{y} 4}{4}\right)$ for perceived tangibility, X11 $\left(\frac{\mathrm{x} 6+\mathrm{x} 7+\mathrm{x} 8+\mathrm{x} 9+\mathrm{x} 10}{5}\right)$ for expected reliability and $\mathrm{Y} 11\left(\frac{\mathrm{y} 6+\mathrm{y} 7+\mathrm{y} 8+\mathrm{y} 9+\mathrm{y} 10}{5}\right)$ for perceived reliability, $\mathrm{X} 16\left(\frac{\mathrm{x} 12+\mathrm{x} 13+\mathrm{x} 14+\mathrm{x} 15}{4}\right)$ for expected responsiveness and $\mathrm{Y} 16\left(\frac{\mathrm{y} 12+\mathrm{y} 13+\mathrm{y} 14+\mathrm{y} 15}{4}\right)$ for perceived responsiveness, $\mathrm{X} 21\left(\frac{\mathrm{x} 17+\mathrm{x} 18+\mathrm{x} 19+\mathrm{x} 20}{4}\right)$ for expected assurance $\mathrm{Y} 21\left(\frac{\mathrm{y} 17+\mathrm{y} 18+\mathrm{y} 19+\mathrm{y} 20}{4}\right)$ for perceived assurance, X27 $\left(\frac{\mathrm{x} 22+\mathrm{x} 23+\mathrm{x} 24+\mathrm{x} 25+\mathrm{x} 26}{5}\right)$ for expected empathy Y27 $\left(\frac{\mathrm{y} 22+\mathrm{y} 23+\mathrm{y} 24+\mathrm{y} 25+\mathrm{y} 26}{5}\right)$ for perceived empathy. The questionnaire was pilot-tested among 25 bank's executives and respondents, consequently some questions paraphrasing were added to avoid confusion. The questionnaires coupled with the covering letter were handled to every response base. The response rate was 89.5 percent, as the completed and returned questionnaires were537 out of 600 questionnaires. Finally, SPSS release ten was used as a data analysis package. a parametric statistical technique such as multiple regression and a nonparametric statistical technique such as Wilcoxon Signed Ranks Test (WSRT) were deployed. Also, multivariate, bivariate, and univariate analysis were utilized in the current study.

\section{The Study Findings}

In this part of the study, sample normality, regressors multi-collinearity, scale validity, reliability, hypotheses testing, conclusion, recommendations, and limitations will be discussed.

\subsection{Normality, Multi-Collinearity, Validity, and Reliability}

Data distribution's shape is considered normal when the sample size is bigger than 30 cases (Ortuzar \& Willumsen, 1994). Consequently, normality dimension is assumed, as sample's size is 537 cases in the current study. Statistically, instrument and concepts are considered reliable when the value of Cronbach alpha coefficient is bigger than 60 percent (Foster, 2001, p. 228; Teo \& King, 1996; Malhotra, 1993, p. 308).

Table 1.Reliability of Instrument (Scale) and concepts

\begin{tabular}{llll}
\hline Instrument (Scales) & N & N of Items & Alpha \\
\hline The whole questionnaire (excluding the demographics) & 537 & 59 & 0.982 \\
Tangibility Concept & 537 & 8 & 0.937 \\
Reliability Concept & 537 & 10 & 0.927 \\
Responsiveness Concept & 537 & 8 & 0.914 \\
Assurance Concept & 537 & 8 & 0.92 .9 \\
Empathy Concept & 537 & 10 & 0.928 \\
\hline
\end{tabular}

As shown in Table 1, Cronbach alpha coefficients are 98.2, 93.7, 92.7, 91.4, 92.9, and 92.8 percentfor the whole instrument's items, tangibility, reliability, responsiveness, assurance, and empathy concepts respectively. Therefore, reliability dimension in the current study is supported. Multi-collinearity amongst study's regressors 
i.e. gender, age, income, education, and occupation is supported, as all correlations' coefficients show values less than unity, as shown in Table 2.

Table 2.Multi-collinearity Matrix of the Independent Variables (Regressors)

\begin{tabular}{|c|c|c|c|c|c|}
\hline \multirow[t]{2}{*}{ Independent Variables } & \multicolumn{5}{|c|}{ Independent Variables } \\
\hline & Gender & Age & Income & Occupation & Education \\
\hline Gender & -- & & & & \\
\hline Age & .042 & -- & & & \\
\hline Income & .010 & .175 & -- & & \\
\hline Occupation & .002 & .125 & .009 & -- & \\
\hline Education & .006 & .227 & .168 & .112 & -- \\
\hline
\end{tabular}

For instrument's validity, the current research used a ready-made questionnaire that was designed by Parasuramanet al., (1991) to assess banking service quality. However, grouped discussions, with bankers customers and colleagues, suggest some minor paraphrasing and typo amendments. Literally, validity refers to the extent to which a test measures the concept(s) that it intends or claims to measure [Bryman and Cramer, (1999); Rust and Golomok, (1999); Kline, (1997); and Nunnally, (1978)]. Unlike reliability, there is no single figure which indicates test validity (Kline, 1997). Stodnicket al., (2008); Saravananet al., (2007); Lotayif, (2003; Lotayif, 2004a and; Lotayif 2004b); Lotayif and El-Ragal, (2004),Keil et al.,(2000), Ravichandran and Rai, (2000); Bryman and Cramer, (1999); Rust and Golomok, (1999); Chan et al.,(1998); Kline, (1997); Wonnacott and Wonnacott, (1990); Ghiselli et al., (1981); and Nunnally, (1978) distinguish between types of validity. These types are face, contents, predictive (criterion-related validity), construct, concurrent, convergent, divergent, and discriminant validities.

Table 3.Number of Dimensions within the Expectation Side of SERVQUAL Scale

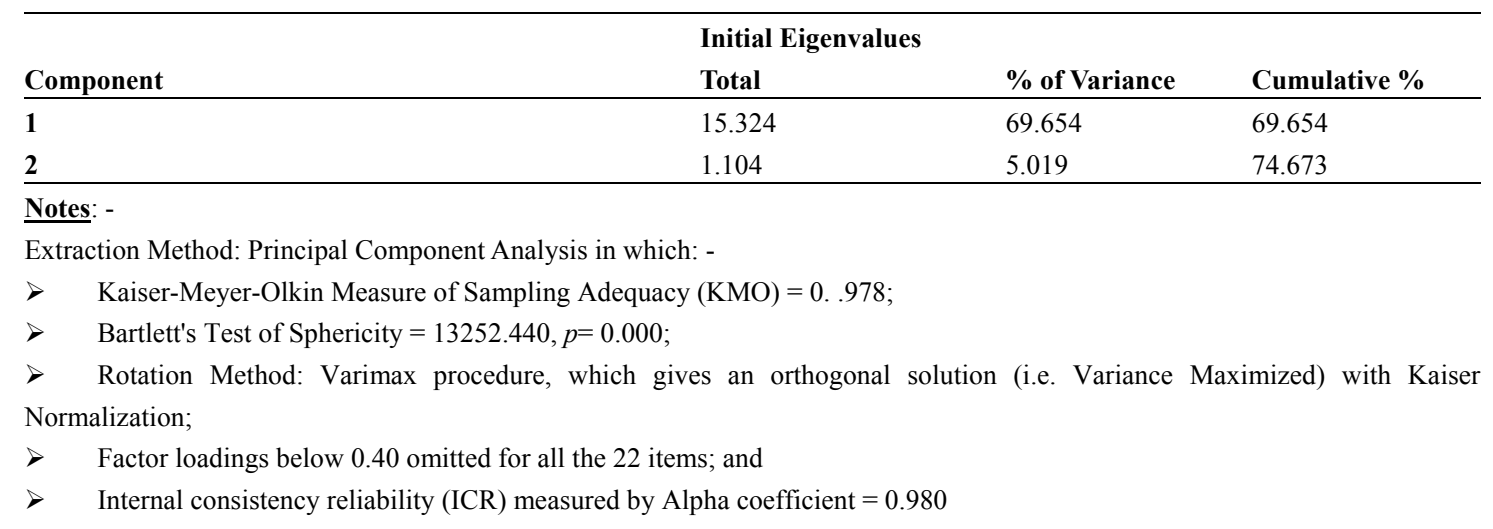

Face validity refers to the appearance of the instrument. Therefore, it includes everything related to collect the required data for the intended purposes, from questions design and order, to number of questions and so on. Face validity is measured by judgmental methods e.g. careful definition of the topic, items to be scaled, scale to be used and so on (El-Ragal, 2001). Content validity refers to the extent to which the instrument provides adequate coverage of the topic being researched (Rust \& Golomok, 1999). To ensure these two kinds of validity, the SERVQUAL scale was piloted on fellow academics for consultation as well as industry participants, and amended in the light of comments and recommendations made. Construct validity refers to identify the underlying construct(s) being measured and determine how well the test represents them. It is usually measured by factor analysis (Bryman \& Cramer, 1999). In the current study, construct validity testing revealed that SEVQUAL scale is loaded upon two dimensions, as shown in Tables $(3,4$, and 5). These two dimensions are "responsiveness-assurance-empathy" and "tangibles-reliability" as revealed in expectation side of the SERVQUAL scale in Table 4. 
Table 4. Number of Dimensions in SERVQUAL Scale

\begin{tabular}{|c|c|c|c|c|c|}
\hline \multicolumn{3}{|c|}{$\begin{array}{l}\text { SERVQUAL Dimensions } \\
\text { (Expectation) }\end{array}$} & \multicolumn{3}{|c|}{$\begin{array}{l}\text { SERVQUAL Dimensions } \\
\text { (Perception) }\end{array}$} \\
\hline $\begin{array}{l}\text { Five-dimension } \\
\text { SERVQUAL Scale } \\
\text { items) }\end{array}$ & $\begin{array}{l}\text { Responsiveness } \\
\text { (22-Assurance } \\
\text {-Empathy } \\
\end{array}$ & $\begin{array}{l}\text { Tangibles- } \\
\text { Reliability }\end{array}$ & $\begin{array}{l}\text { Five-dimension } \\
\text { SERVQUAL Scale } \\
\text { items) }\end{array}$ & $\begin{array}{l}\text { Assurance- } \\
\text { (22Empathy }\end{array}$ & $\begin{array}{l}\text { Tangibles-Reliability- } \\
\text { Responsiveness }\end{array}$ \\
\hline TangiblesX1 & & .795 & Y1 & & .811 \\
\hline $\mathrm{X} 2$ & & .812 & Y2 & & .788 \\
\hline $\mathrm{X} 3$ & & .816 & Y3 & & .814 \\
\hline $\mathrm{X} 4$ & & .804 & Y4 & & .803 \\
\hline ReliabilityX6 & & .658 & Y6 & & .741 \\
\hline $\mathrm{X} 7$ & & .645 & Y7 & & .654 \\
\hline $\mathrm{X} 8$ & & .645 & Y8 & & .682 \\
\hline X9 & & .647 & Y9 & & .665 \\
\hline $\mathrm{X} 10$ & & .630 & Y10 & & .700 \\
\hline Responsiveness $\mathrm{X} 12$ & .626 & & Y12 & & .604 \\
\hline $\mathrm{X} 13$ & .611 & & Y13 & & .648 \\
\hline $\mathrm{X} 14$ & .674 & & Y14 & & .642 \\
\hline $\mathrm{X} 15$ & .661 & & Y15 & & .595 \\
\hline Assurance X17 & .761 & & Y17 & .653 & \\
\hline $\mathrm{X} 18$ & .789 & & Y18 & .640 & \\
\hline X19 & .780 & & Y19 & .757 & \\
\hline $\mathrm{X} 20$ & .751 & & Y20 & .718 & \\
\hline Empathy X22 & .779 & & Y22 & .788 & \\
\hline $\mathrm{X} 23$ & .735 & & Y23 & .811 & \\
\hline $\mathrm{X} 24$ & .800 & & Y24 & .814 & \\
\hline $\mathrm{X} 25$ & .809 & & Y25 & .784 & \\
\hline $\mathrm{X} 26$ & .809 & & Y26 & .795 & \\
\hline \multicolumn{6}{|l|}{ Note:- } \\
\hline$>\quad \mathrm{X} 1$ to $\mathrm{X26}$ repre & ent the 22 items in SE & VQUAL scale. & & & \\
\hline
\end{tabular}

In the perception side of SERVQUAL scale, the two dimensions are "tangibles-reliability" and "responsiveness-assurance-empathy", as shown in Tables (4, and 5).Consequently, the current study is not ensuring the five dimensions of SERVQUAL scale suggested by Parasuraman et al.,(1991). However, its reliability is ensured, as Cronbach alpha coefficients are 0.980 , and 0.920 for the expected and perceived side of SERVQUAL scale respectively, as shown in Tables (3 and 4).

Table 5. Number of Dimensions within the Perception Side of SERVQUAL Scale

\begin{tabular}{llll}
\hline & \multicolumn{2}{l}{ Initial Eigenvalues } & \\
Component & Total & \% of Variance & Cumulative \% \\
\hline $\mathbf{1}$ & 14.723 & 66.924 & 66.924 \\
$\mathbf{2}$ & 1.240 & 5.637 & 72.560 \\
\hline
\end{tabular}

Notes: -

Extraction Method: Principal Component Analysis in which: -

$>\quad$ Kaiser-Meyer-Olkin Measure of Sampling Adequacy $(\mathrm{KMO})=0.974$;

$>\quad$ Bartlett's Test of Sphericity $=12311.833, p=0.000$

$>$ Rotation Method: Varimax procedure, which gives an orthogonal solution (i.e. Variance Maximized) with Kaiser Normalization;

$>$ Factor loadings below 0.40 omitted for all the 22 items; and

> Internal consistency reliability (ICR) measured by Alpha coefficient $=0.920$

Predictive validity/Criterion-related validity refers to ability of a test to predict some relevant outcome (Saravananet et al., 2007). To assess this kind of validity, criterion to be compared with should be available. However, it is difficult to set up a good criterion to upon which to base predictions. Therefore, predictive validity 
is of little use (Bryman and Cramer, 1999). To test criterion-related validity, Kuo (2003) proposed correlating SERVQUAL scale with overall service quality, loyalty, and overall customer satisfaction. The current study did not address that topic, as its main concern is the assessment of banking services. Therefore, other scholars are invited to conduct that in a Middle East context. However, other scholars e. g. Saravanan et al., (2007) have tackled that issue in a developing nation context (Indian automobile service sector). Concurrent validity refers to correlating a test with another test of the same variable (Rust and Golomok, 1999). Satisfactory concurrent validity requires a correlation of at least 0.7 between the two tests (El-Ragal, 2001). Scales differences impose restrictions on conducting this kind of validity. Discriminant validity refers to the strength of correspondence between a measure and other measures which are supposed to represent other concepts (Bryman and Cramer, 1999). Ghiselli et al.,(1981) stated that correlation coefficient greater than 0.80 represent extreme cases. Finally, convergent validity refers to the attempt to demonstrate that each measure harmonizes with another measure (El-Ragal, 2001; Bryman \& Cramer, 1999; Chan 1996). Using observations in addition to the questionnaire could guarantee this kind of validity a procedure not followed here (El-Ragal, 2001).

\subsection{Hypotheses Testing}

As shown in Table (6) and based on Multiple Regression (MR) results, there are significant relationships between every expected SERVQUAL dimension (i.e. tangibility, reliability, responsiveness, assurance, and empathy) and UAE customers' demographics (i.e. gender, age, income, occupation, and education), as $p<0.05$. Consequently, the alternative hypotheses $(\mathrm{H} 1 E),(\mathrm{H} 2 \mathrm{E}),(\mathrm{H} 3 E),(\mathrm{H} 4 \mathrm{E})$, and $(\mathrm{H} 5 E)$ are supported. The most remarkable things are:

- Customers' expectations of service quality (measured by the SERVQUAL dimensions) are affected by their demographics.

- Data entry order process did not affect on its analysis, as Durbin-Watson test reported values $>1.4$ for all dependent variables, as shown in Table 6.

- The explanation powers of these models are weak, as "R square" and "adjusted R" values indicate. More specifically, these five IV's are responsible only for $0.043,0.037,0.054,0.056$ and 0.053 of the behaviours of tangibility, reliability, responsiveness, assurance, and empathy respectively.However, if the adjusted $\mathrm{R}$ square has been taken into consideration, the magnitude of IVs shrink to small proportions, as shown in Table 6.

Statistically, if the MR model is significant it does not mean that all the independent variables within the regression equation have significant relationships with the dependent variable, but it does mean that only (at least) one significant relationship exist (Ashour, 1993). Therefore it is necessary to determine the effect that each independent variable has in the MR equation. More specifically, occupation is the only independent variable that has significant relationship with all expected SERVQUAL dimensions, as $p=0.000<0.05$. Consequently, the following alternative hypotheses $\boldsymbol{H} 1 E d, H 2 E d, H 3 E d, H 4 E d$, and $H 5 E d$ are supported. Only gender and occupation regressors report significant relationships in the expected assurance and empathy equations, as $p=$ $0.031,0.00,0.00$, and $0.006<0.05$ respectively, as shown in Table (7). Therefore, the alternative hypotheses

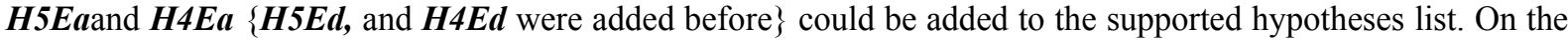
other hand, H1Ea, H1Eb, H1Ec,H1Ee, (fortangibility) H2Ea, H2Eb, H2Ec, H2Ee, (for reliability) H3Ea, $\mathrm{H} 3 \mathrm{~Eb}, \mathrm{H} 3 \mathrm{Ec}, \mathrm{H} 3 \mathrm{E} e$, (for responsiveness) H4Eb, H4Ec, H4Ee (for assurance), H5Eb, H5Ec, and H5Ee (for empathy) are not supported, as $p>0.05$ with all these variables, as shown in Table (7). To sum up the expected side of SERVQUAL scale, no significant relationships exist between tangibility and gender, age, income, and education. Also, no significant relationships exist between reliability and gender, age, income, and education. No significant relationships exist between responsiveness and gender, age, income, and education. No significant relationships exist between assurance and age, income, and education. Finally, no significant relationships exist between empathyand age, income, and education. 
Table 6. Multiple Regressions between the demographics and SERVQUAL dimensions

\begin{tabular}{|c|c|c|c|c|c|c|c|}
\hline Customers' Expectation & $\mathbf{F}$ & $P$-value & $\mathbf{R}$ & R Square & $\begin{array}{l}\text { Adjusted } \\
\text { Square } \\
\end{array}$ & $\mathbf{R}$ & $\begin{array}{l}\text { Durbin-Wat } \\
\text { son }\end{array}$ \\
\hline - $\quad$ Tangibility & 4.814 & $0.000 * * *$ & 0.208 & 0.043 & 0.034 & & 1.491 \\
\hline - $\quad$ Reliability & 4.087 & $0.001 * * *$ & 0.193 & 0.037 & 0.028 & & 1.423 \\
\hline - $\quad$ Responsiveness & 6.054 & $0.000 * * *$ & 0.232 & 0.054 & 0.045 & & 1.461 \\
\hline - $\quad$ Assurance & 6.323 & $0.000 * * *$ & 0.237 & 0.056 & 0.047 & & 1.517 \\
\hline - $\quad$ Empathy & 5.940 & $0.000 * * *$ & 0.230 & 0.053 & 0.044 & & 1.529 \\
\hline \multicolumn{8}{|l|}{ Customers' Perception } \\
\hline - $\quad$ Tangibility & 2.380 & $0.038 * * *$ & 0.148 & 0.022 & 0.013 & & 1.469 \\
\hline - $\quad$ Reliability & 2.134 & 0.060 & 0.140 & 0.020 & 0.010 & & 1.418 \\
\hline - $\quad$ Responsiveness & 2.637 & $0.023 * * *$ & 0.156 & 0.024 & 0.015 & & 1.466 \\
\hline - $\quad$ Assurance & 2.700 & $0.020 * * *$ & 0.157 & 0.025 & 0.016 & & 1.496 \\
\hline Empathy & 3.428 & $0.005 * * *$ & 0.177 & 0.031 & 0.022 & & 1.441 \\
\hline
\end{tabular}

Notes:-

$>\quad(* * *)$ There is a significant relationship between at least one of the independent variables and model dependent variable as $p<$ 0.05. Therefore, the model variables' coefficients should be explained in a bivariate analysis (i.e. correlations amongst these variables);

$>\quad$ R Square $=$ indicates the effects the independent variables have on the dependent one in the sample;

$>\quad$ Adjusted R Square $=$ reflects the model goodness of fit for the population; and

$>$ Durbin-Watson is a test to indicate the effect of data entry order on the analysis, therefore if it is $>1.4$, it means the order has no effect on the analysis,and if it is less than 1.4, it means the order has affected the analysis (Stat graphics 2000). Durbin-Watson values range from zero to four. Whilst a value close to zero indicates strong positive correlation, a value of four indicates strong negative correlation. But vales between 1.5 and 2.5 indicate acceptable level of independency amongst variables (Durbin and Watson, 1971).

In the perception side of the SERVQUAL scale, the alternative hypotheses $(\boldsymbol{H} 1 \boldsymbol{P}),(\boldsymbol{H} 3 \boldsymbol{P}),(\boldsymbol{H} 4 \boldsymbol{P})$, and $(\boldsymbol{H} 5 \boldsymbol{P})$ are supported, as $p=0.038,0.023,0.020$, and $0.005<0.05$ respectively, as Table (6) indicates. Having said that, significant relationships exist between customers' demographics and perceived SERVQUAL dimensions e.g. tangibility, responsiveness, assurance, and empathy. However, the alternative hypothesis $(\boldsymbol{H} 2 \boldsymbol{P})$ is rejected, as $p$ $=0.060>0.05$ which means there is no significant relationship existed between customer perception of reliability dimension and demographics. Two remarkable things could be noticed here:

- The explanation powers of these models are weak, as " $\mathrm{R}$ square" and "adjusted R" values indicate. More specifically, these five IVs are responsible only for $0.022,0.024,0.025$, and 0.031 of the behaviours of tangibility, responsiveness, assurance, and empathy respectively.

- However, if the adjusted R Square has been taken into consideration, the effect of the independent variables shrink to small proportions, as shown in Table 6 .

Table 7.Explaining the weighted effect of each regressor on the dependent variables

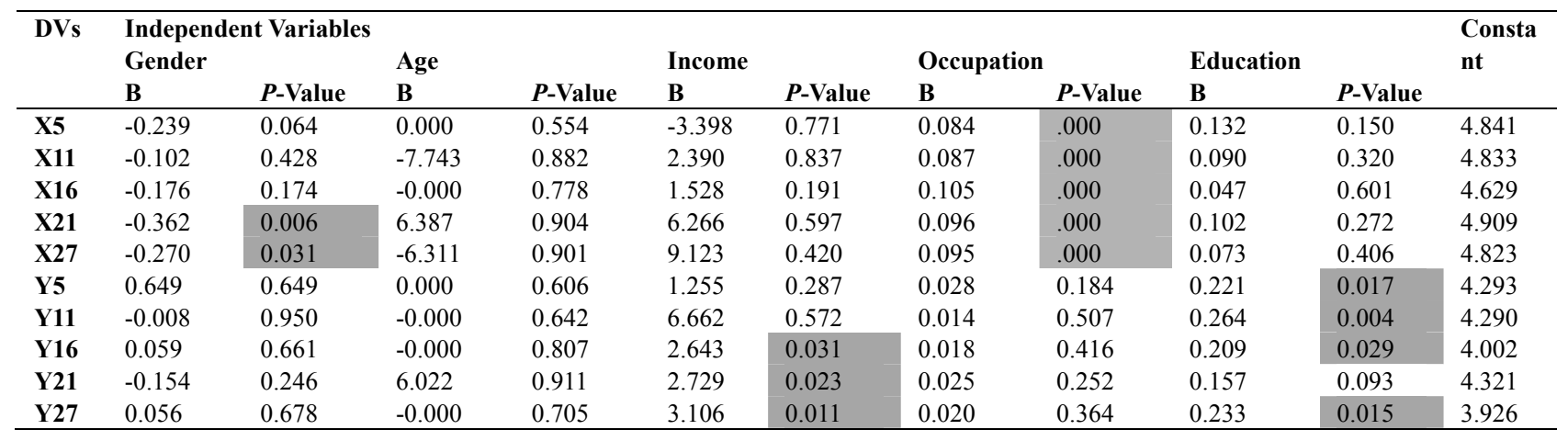




\section{Notes: -}

$\mathbf{X} \mathbf{X}=$ Expected Tangibility, X11 $=$ Expected Reliability, X16 $=$ Expected Responsiveness, $\mathbf{X 2 1}=$ Expected Assurance, and $\mathbf{X 2 7}=$ Expected Empathy;

Y5 = Perceived Tangibility, Y11 = Perceived Reliability, Y16= Perceived Responsiveness, Y21= Perceived Assurance,Y27 = Perceived Empathy;

and $y=\propto+\beta_{1} x_{1}+\beta_{2} x_{2}+\beta_{3} x_{3}+\ldots \ldots .+\beta_{n} x_{n}+\in$ (Cooper and Emory, 1995, p. 499).

Where: -

$y=$ The dependent variable (SERVQUAL 10 dimensions i.e. 5 expected and 5 perceived);

$\propto=$ The value of $y$ if all $\mathrm{X}$ 's equal zero (constant value);

$\beta=$ The general liner model slopes of $x_{i}$, or the response. $\beta$ represent the regression coefficient associated with each $X_{i}$;

$X_{i}=$ The independent variables (e.g. 10 dimensions, 5 expected dimensions and 5 perceived dimensions); and

$\in \stackrel{i}{=}$ Model' error, $\in$ is assumed to be zero.

It is necessary to determine the effect that each independent variable has in the MR equation. In tangibility model, no significant relations exist with gender $(p=0.649>0.05)$, age $(p=0.606>0.05)$, income $(p=0.287>$ 0.05), and occupation $(p=0.184>0.05)$. Therefore, the alternative hypotheses $\boldsymbol{H 1 P a}, \boldsymbol{H} \boldsymbol{P P}, \boldsymbol{H} \mathbf{P c}$, and H1Pd are not supported. In reliability model, no significant relationships exist with gender $(p=0.950>0.05)$, age $(p=$ $0.642>0.05)$, income $(p=0.572>0.05)$, and occupation $(p=0.507>0.05)$. Therefore, the alternative hypotheses $\boldsymbol{H} 2 \boldsymbol{P a}, \boldsymbol{H} 2 \boldsymbol{P b}, \boldsymbol{H} 2 \boldsymbol{P c}$, and $\boldsymbol{H} 2 \boldsymbol{P d}$ are not supported. In responsiveness model, no significant relationships exist with gender $(p=0.661>0.05)$, age $(p=0.807>0.05)$, and occupation $(p=0.416>0.05)$. Therefore, the alternative hypotheses $\boldsymbol{H} \mathbf{3 P a}, \boldsymbol{H} \mathbf{3 P b}$, and $\boldsymbol{H} \mathbf{3 P d}$ are not supported. In assurance model,no significant relationships exist with gender $(p=0.246>0.05)$, age $(p=0.911>0.05)$,occupation $(p=0.252>0.05)$, and

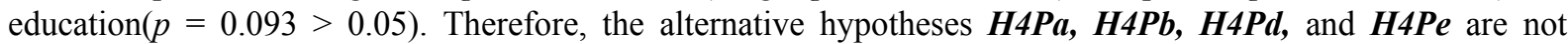
supported. In empathy model,no significant relationships exist with gender $(p=0.678>0.05)$, age $(p=0.705>$ 0.05), and occupation ( $p=0.364>0.05)$. Therefore, the alternative hypotheses $\mathbf{H 5 P a}, \boldsymbol{H 5 P b}$, and $\boldsymbol{H 5 P d}$, are not supported.

For the third objective of the current study and based on Wilcoxon Test, the alternative hypotheses $\boldsymbol{H 6}, \boldsymbol{H 6}_{1}, \boldsymbol{H \boldsymbol { 6 } _ { 2 }}$, $\mathbf{H 6}_{3}, \mathbf{H 6}_{4}$, and $\mathbf{H 6}_{5}$ are supported, as $P=0.000 \leq 0.05$, as shown in Table (8). More specifically, $P=0.000 \leq 0.05$ is an inductive that the difference between every expected and perceived item is not zero (i.e. could be plus or minus). The univariate analysis (represented by median, mean, and summation) confirmed that the expected level of baking services exceed the perceived level with all SERVQUAL dimensions. More specifically, all differences between perception and expectation (P-E) show negative values range from - 0.750 to -1.00 and from - 0.451 to -0.639 for median and mean respectively, as shown in Table (8). To bridge these gaps, too much work is needed to enhance the performance of UAE banks. SERVQUAL dimensions represent the pillars to be proposed for that enhancing. For tangibility dimension, the following items could be used in developing banking services:

- Banks' equipments to be more modern looking;

- Physical facilities to be more attractive;

- Banks employees to be more smart; and

- Pamphlets and statements to be more attractive.

For reliability dimension, the followings could be used in enhancing the banking services:

- To be up to your promises (i.e. to serve at certain time, with certain quality and so on) ;

- To show a sincere interest in solving customer problems;

- To minimize banks' mistakes, in serving customers;

- To do the follow up services that have been promised before; and

- To insist on error-free records.

For responsiveness dimension, the followings could be the remedy:

- Banks' employees have to tell their customers the exact time needed to accomplish every single service from the beginning;

- To offer prompt banking services whenever asked;

- Employees have to show genuinewillingness to help customers; and

- Employees never excuse by their busyness to respond to customers' requests. 
Table 8. Wilcoxon signed ranks test (WSRT)

\begin{tabular}{|c|c|c|c|c|c|c|c|c|c|c|}
\hline \multirow{3}{*}{$\begin{array}{l}\text { SERVQUAL } \\
\text { Dimension }\end{array}$} & \multirow{2}{*}{\multicolumn{2}{|c|}{$\begin{array}{l}\text { Bivariate Analysis } \\
\text { Wilcoxon Test }\end{array}$}} & \multicolumn{8}{|c|}{ Univariate Analysis } \\
\hline & & & \multicolumn{3}{|c|}{ Median } & \multicolumn{2}{|l|}{ Mean } & & \multicolumn{2}{|l|}{ Sum } \\
\hline & $Z$ value & P-Value & $\mathbf{E}$ & $\mathbf{P}$ & (P-E) & $\mathbf{E}$ & $\mathbf{P}$ & (P-E) & $\mathbf{E}$ & $\mathbf{P}$ \\
\hline Tangibility & -8.844 & $.000 \mathrm{R}$ & 6.000 & 5.250 & -0.750 & 5.484 & 5.033 & -0.451 & 2945.0 & 2702.8 \\
\hline Reliability & -9.217 & $.000 \mathrm{R}$ & 6.000 & 5.200 & -0.800 & 5.560 & 4.951 & -0.609 & 2985.8 & 2659.0 \\
\hline Responsiveness & -9.195 & $.000 \mathrm{R}$ & 6.000 & 5.000 & -1.000 & 5.507 & 4.880 & -0.627 & 2957.2 & 2621.0 \\
\hline Assurance & -9.783 & $.000 \mathrm{R}$ & 6.000 & 5.250 & -0.750 & 5.615 & 5.036 & -0.579 & 3015.5 & 2704.7 \\
\hline Empathy & -9.406 & $.000 \mathrm{R}$ & 6.000 & 5.200 & -0.800 & 5.555 & 4.916 & -0.639 & 2983.4 & 2640.4 \\
\hline
\end{tabular}

Note: -

$>\quad \mathbf{R}=$ Rejecting the null hypothesis that; "the median of the population difference $\left(\mathrm{X}_{\mathrm{i}} . \mathrm{Yi}=\mathrm{D}\right)$ is zero", as $p \leq 0.05$;

$>\quad \mathbf{E}$ represents customer's expectation, and $\mathbf{P}$ represents customer's perception;

$>\quad$ Median is the score in the centre of the sample;

$>\quad$ Mean means adding up all the values and divide by the number of values; and

$>\quad$ Sum is the total score of that variable within the sample.

For assurance dimension, the followings could be the remedy:

- The behaviour of employees have to instil confidence in customers;

- Make your customer feel safe in there transactions with your bank;

- Banks' employees are consistently courteous and polite with customers; and

- Sufficient knowledge and authority to be given to employees to enable them to answer customers' questions.

For empathy dimension, the followings could be the remedy:

- Give personal attention to every individual customer;

- Operating hours to be convenient to all customers;

- Try to customize banks' services to better satisfy customers;

- Let customers feel that theirbest interests been taken at heart; and

- To invest in marketing research to better understand customers' needs.

\section{Conclusion}

Face and content validities of SERVQUAL scale are supported. However, construct validity is not supported, as the 22-item scale is loaded upon two main factors: "responsiveness-assurance-empathy" and "tangibles-reliability" for service expectation and "tangibles-reliability" and"responsiveness-assurance-empathy" for service perception. The expectations of banking services in UAE are affected by customer's demographics. Therefore, few models are existed:

(1) Tangibility dimension and demographics i.e. gender, age, income, occupation, and education;

(2) Reliability dimension and demographics i.e. gender, age, income, occupation, and education;

(3) Responsiveness dimension and demographics i.e. gender, age, income, occupation, and education;

(4) Assurance dimension and demographics i.e. gender, age, income, occupation, and education; and

(5) Empathy dimension and demographics i.e. gender, age, income, occupation, and education.

Also, the perceptions of banking services in UAE are affected by customer's demographics. Therefore, few models are existed:

(1) Tangibility dimension and demographics i.e. gender, age, income, occupation, and education;

(2) Responsiveness dimension and demographics i.e. gender, age, income, occupation, and education;

(3) Assurance dimension and demographics i.e. gender, age, income, occupation, and education; and

(4) Empathy dimension and demographics i.e. gender, age, income, occupation, and education.

The baking services in UAE lagging behind customers expectations, therefore banks are invited to rethink in their adopted strategies. SERVQUAL dimensions help guide that restructuring process. 


\subsection{Limitations and Recommendations}

- As current study depended mainly on SERVQUAL iteration proposed by Parasuraman et al., (1991),criterion-related validity was not conducted. Therefore, other researchers are invited to correlate some other variables such as overall service quality, loyalty, and overall customer satisfaction with SERVQUAL as proposed by Kuo, (2003)and others e.g. Saravanan et al., (2007).

- As only structured questionnaire (not coupled with observation) was used as a data collection tool, convergent validity was out of reach. Other scholars are invited to add concurrent, discriminant, and convergent validities in a Middle east context.

- As the explanation powers of multiple regression models are weak, other regressors rather than those used in the current study are recommended to be added.Consequently, other scholars are invited to explore other variables.

\section{References}

Aga, M., \& Okan, V. S. (2007). An Empirical Investigation of Service Quality and Customer Satisfaction in Professional Accounting Firms: Evidence from North Cyprus. Problems and Perspectives in Management, 5(3), 84-98.

Ashour, S. (1993).Statistical Analysis and Presentation by Using SPSS. Cairo Statistical Institute, Cairo University Press, Egypt.

Babakus, E., \& Boller, G. W. (1992). An Empirical Assessment of the SERVQUAL Scale", Journal of Business Research, 24, 253-268.https://doi.org/10.1016/0148-2963(92)90022-4

Berry, L. (1994). On Great Service. Free Press, NY.

Bryman, A., \& Cramer, D. (1999). Quantitative Data analysis with SPSS Release 8 for Windows: A Guide for Social Scientists. London: Routledge. https://doi.org/10.4324/9780203459621

Chan, Y., Huff, S., \& Copeland, D. G. (1998). Assessing Realized Information Systems Strategy", Journal of Strategic Information Systems, 6, 273-298. https://doi.org/10.1016/S0963-8687(97)00005-X

Cooper, D., \& Emory, C. W. (1995). Business Research Methods. Richard D. Irwin, INC., USA.

Cuthbert, P. (1996). Managing Service Quality in HE: is SERVQUAL the Answer? Managing Service Quality, 6(2), 11-16. https://doi.org/10.1108/09604529610109701

Davidow, W. H., \& Uttal, B. (1989). Total Customer Service: The Ultimate Weapon. New York: Harper and Row.

Donnelly, M., \& Shiu, E. (1999). Assessing Service Quality and its Link With Value For Money in A UK Local Authority's Housing Repairs Service Using The SERVQUAL Approach. Total Quality Management, (July), 498-505.https://doi.org/10.1080/0954412997451

Donthu, N.,\&Yoo, B. (1998).Cultural Influences on Service Quality Expectations. Journal of Service Research, 1, 178-186.https://doi.org/10.1177/109467059800100207

Durbin, J.,\& Watson, G. S. (1971).Testing for Serial Correlation in Least-Squares Regression. III Biometrika, 58, 1-19. https://doi.org/10.2307/2334313

El-Ragal, A. (2001).Building DSS Using Knowledge Discovery in Database Techniques: Applied to Admissions and Registration Functions. Unpublished PhD Thesis, Business School, University of Plymouth, UK.

Fatma, P., \& Harwood, T. N. (2005).Patient Satisfaction in a Preoperative Assessment Clinic: An Analysis Using SERVQUAL Dimensions. Total Quality Management and Business Excellence, 16(1), 15-30.https://doi.org/10.1080/1478336042000255622

Foster, J. (2001). Data Analysis Using SPSS for Windows(2nd eds.). Sage Ltd., London.

Garvin, D. A. (1988).Managing Quality: The Strategic and Competitive Edge. NY: Free Press.

Ghiselli, E., Campbell, J., \& Zedeck, S. (1981). Measurement Theory for the Behavioral Sciences. W. H. Freeman, San Francisco, USA.

Ghobadian, A., Speller, S., \& Jones, M. (1994). Service Quality Concepts and Models. International Journal of Quality \& Reliability Management, 11(9), 43-66. https://doi.org/10.1108/02656719410074297

Gronroos, C. (1993). Toward a Third Phase in Service Quality Research: Challenges and Future Directions. In T. A. Swartz; D. E. Bowen; S. W. Brown (Eds.), Advances in Services Marketing and Management: Research and Practice (pp. 49-64).JAI Press, Greenwich, CT. 
Gummesson, E. (1991). Service Quality: A Holistic View. In S.W. Brown, E; Gummesson, B., Edvardsson, \& B. Gustavsson (Eds.), Service Quality: Multidisciplinary and Multinational Perspectives. Lexington, Mass, Lexington Books.

Hair, J. F. J. R., Anderson, R. E., Tatham, R. L.,\& Black, W. C. (1998). Multivariate Data Analysis. Prentice-Hall Inc., USA.

Hughey, D., Chawla, S., \& Kahn, Z. (2003).Measuring the Quality of University Computer Labs Using SERVQUAL: A longitudinal Study.The Quality Management Journal, 10(3), 33-44.

Jackson, D., \& Humble, J. (1994). Service Excellence - the Role of Information Technology. Managing Service Quality, 4(4), 36-40. https://doi.org/10.1108/09604529410085827

Kasper, H. P., Van, H., \& Vries, Jr. (1999).Service Marketing and Management: An International Perspective. Chichester, England, Wiley.

Keil, M., Mann, J., \& Rai, A. (2000).Why Software Projects Escalate: An Empirical Analysis and Test of Four Theoretical Models. MIS Quarterly, 24(4), 631-664.https://doi.org/10.2307/3250950

Kelley, S. W. (1992). Developing Customer Orientation Among Service Employees. Journal of the Academy of Marketing Science, 20(1), 27-36. https://doi.org/10.1007/BF02723473

Kelley, S. W. (1993). Discretion and the Service Employee. Journal of Retailing, 69(1), 104-126. https://doi.org/10.1016/S0022-4359(05)80005-3

Klaus, P., \& Stan, M. (2007).The Role of Brands in a Service-Dominated World. Brand Management, 15(2), (November), 115-122.https://doi.org/10.1057/palgrave.bm.2550121

Kline, P. (1997). An Easy Guide for Factor Analysis. Routledge, London.

Kline, P. (2001). The Handbook of Psychological Testing (2nd ed.). London: Routledge.

Kuo, Y. (2003). A Study on Service Quality of Virtual Community Websites. Total Quality Management and Business Excellence, 14(4), 461-473. https://doi.org/10.1080/1478336032000047237a

Lam, S. S. K., \& Woo, K. S. (1997). Measuring Service Quality: A Test-Retest Reliability Investigation of SERVQUAL. Journal of the Market Research Society, 39(2), 381-390.

Lewis, B. R. (1996). Customer Care in Services. In Olsen, M. D; Teare, R., \& E. Gummesson (Eds.), Service Quality in Hospitality Organizations (pp. 57-88). London: Cassell.

Lewis, B. R.,\& Mitchell, D. (1990). Defining and Measuring the Quality of Customer Service. Marketing Intelligence and Planning, 8(6), 11-17. https://doi.org/10.1108/EUM0000000001086

Lotayif, M. (2003).A Theoretical Model for Matching Entry Modes with Defensive Marketing Strategies", The Journal of American Academy of Business, Cambridge (JAABC), 2(2), 460-466.

Lotayif, M. (2004a). Factors that Affect the Selection of Defensive Marketing Strategies: Evidence from the Egyptian Banking Sector. The Journal of American Academy of Business, Cambridge, 4(1\&2), 152-158.

Lotayif, M. (2004b). GATS Impacts on Entry Modes and Defensive Marketing Strategies in the Egyptian Banking Sector. Published PhD Thesis, Plymouth Business School, University of Plymouth. http://hdl.handle.net/10026.1/1660

Lotayif, M., \& El-Ragal, A. (2004).Investigating and Modeling GATS Impacts on the Developing Countries: Evidence from the Egyptian Banking Sector. The Journal of American Academy of Business, Cambridge, 4(1\&2), 496-502.

Malhotra, N. K. (1993). Marketing Research an Applied Orientation. Prentice-Hall, Inc., New Jersey, USA.

Mattila, M. (1999). The Role of Culture in the Service Evaluation Process. Journal of Service Research, 1, 250-261.https://doi.org/10.1177/109467059913006

Mcatarsney, D. (1999). Review, Critique and Assessment of Customer Care. Total Quality Management, 636-646.https://doi.org/10.1080/0954412997622

Mittal, B., \& Lassar, W. M. (1996). The Role of Personalization in Service Encounters. Journal of Retailing, 72(1), (Spring), 95-110.https://doi.org/10.1016/S0022-4359(96)90007-X

Nunnally, J. C. (1978). Psychometric Theory (2nd ed.). New York: McGraw-Hill.

Oldfield, B., \& Baron, S. (2000). Student Perceptions of Service Quality in a UK University, Business and 
Management Faculty. Quality Assurance in Education, 8(2), 85-95. https://doi.org/10.1108/09684880010325600

Oliver, R. (1997). A Behavioral Perspective on the Consumer. New York: McGraw-Hill.

Ortuzar, J. D., \&Willumsen, L. G. (1994). Modelling Transport. John Wiley and Sons Ltd, New York.

Parasuraman, A., Berry, L. L., \& Zeithaml, V. A. (1991). Refinement and Reassessment of the SERVQUAL Scale. Journal of Retailing, 67, 420-450.

Parasuraman, A., Zeithaml, V. A., \& Berry, L. L. (1985). A Conceptual Model of Service Quality and its Implications for Future Research. Journal of Marketing, 49, 41-50.https://doi.org/10.2307/1251430

Parasuraman, A., Zeithaml, A. V., \& Berry, L. L. (1988). SERVQUAL: A Multiple-Item Scale for Measuring Consumer Perceptions of Service Quality. Journal of Retailing, 64(Spring), 12-40.

Pariseau, S. E., \& McDaniel, J. R. (1997). Assessing Service Quality in Schools of Business. International Journal of Quality \& Reliability Management, 204-219.https://doi.org/10.1108/02656719710165455

Perng, Y. H., Yi-Ping, H., \& Hui-Jung, L. (2007). A Service Quality Improvement Dynamic Decision Support System for Refurbishment Contractors. Total Quality Management, 18(7), 731-749.https://doi.org/10.1080/14783360701349716

Philip, G., \& Hazlett, S. (1997). The Measurement of Service Quality: A New P-C-P Attributes Model, International Journal of Quality \& Reliability Management, 14(2-3), 260-287. https://doi.org/10.1108/02656719710165482

Ravichandran, T., \& Rai, A. (2000). Quality Management in Systems Development: An Organizational System Perspective. MIS Quarterly, 24(3), 381-415. https://doi.org/10.2307/3250967

Reeves, C. A., \& Bednar, D. (1994). Defining Quality: Alternatives and Implications. Academy of Management Review, 19, 419-445. https://doi.org/10.5465/AMR.1994.9412271805

Rust, J., \& Golombok, S. (1999). Modern Psychometrics (2nd ed.). London: Routledge.

Rust, R. T., \& Oliver, R. L. (1994). Service quality: Insights and Managerial Implications from the Frontier. In R.T. Rust \& R. L. Oliver (Eds.), Service Quality: New Directions in Theory and Practice. Thousand Oaks, CA, Sage.

Saravanan, R., \& Rao, K. S. P. (2007). Measurement of Service Quality from the Customer's Perspective-An Empirical Study. Total Quality Management, 18(4), 435-449. https://doi.org/10.1080/14783360701231872

Stat graphics (2000). The Manual of Stat Graphics.

Stodnick, M., \& Pamela, R. (2008). Using SERVQUAL to Measure the Quality of the Classroom Experience. Decision Sciences of Journal Innovative Education, 115-134.https://doi.org/10.1111/j.1540-4609.2007.00162.x

Teo, T., \& King, W. (1996). Assessing the Impact of Integrating Business Planning and IS Planning. Information and Management, 30, 309-321. https://doi.org/10.1016/S0378-7206(96)01076-2

Ugboma, C., Innocent, C. O., Ogochukwu, U., \& Kenneth, N. (2007).Service Quality and Satisfaction Measurements in Nigerian Ports: an Exploration. Maritime Policy\& Management, 34(4), 331-346.https://doi.org/10.1080/03088830701539073

Wisniewski, M. (2001).Assessing Customer Satisfaction with Local Authority Services Using SERVQUAL. Total Quality Management, (December), 995-1003. https://doi.org/10.1080/09544120100000026

Wonnacott, T. H., \& Wonnacott, R. J. (1990). Introductory Statistics for Business and Economics. John Wiley and Sons Inc.

Yavas, U. (2006). How Similar are Frontline Bank Employees' Perceptions of Service Quality to Their Customers? A study of Female Customers and Employees in Turkey. Journal of Financial Services Marketing, 12, 130-138.

Zhao, X., Bai, C., \& Hui, Y. V. (2002). An empirical Assessment and Application of SERVQUAL in a Mainland Chinese Department Store. Total Quality Management, 13(2), 241-255. https://doi.org/10.1080/09544120120102478 


\section{Copyrights}

Copyright for this article is retained by the author(s), with first publication rights granted to the journal.

This is an open-access article distributed under the terms and conditions of the Creative Commons Attribution license (http://creativecommons.org/licenses/by/4.0/). 